\title{
Analysis of English-Speaking Performance for the Effective Language Learning in Digital Era
}

\author{
Fitri Amalia Shintasiwi ${ }^{1, *}$ Khoirul Anwar $^{2}$ \\ 1,2 Social Science Education, Faculty of Social Sciences, Universitas Negeri Semarang \\ *shintasiwi@mail.unnes.ac.id
}

\begin{abstract}
English speaking is highly important for people nowadays due to the fact that English is recognized as a global language that is used all around the world. Additionally, it has a significant role to assist people in communicating with others in many aspects of life, including Indonesia. Universitas Negeri Semarang which encourages internationalization in its institution is expected to create students who have good English-speaking skills when they are going to apply for jobs after graduation. English is also important to be an answer for facing the rapid movement of digitalisation. Thus, this research aims to identify various mistakes often carried out by the students of the Faculty of Social Sciences as a non-English student department in speaking, so the factors which affect their performance in class will be analysed. This research used the descriptive-qualitative method by describing in depth the findings in data analysis based on the research findings. The data sources were in the form of video presentations in English and transcriptions of in-depth interviews with the students of Faculty of Social Sciences, Universitas Negeri Semarang. The research results show that there are various factors that influence the performance of English both linguistically and non-linguistically. The linguistic factor includes their grammar mistakes, lack of vocabulary, pronunciation and local accent. On the other hand, lack of motivation, confidence, and English knowledge also contributed to their anxiety in learning English in class, especially in speaking performance. After analysing those factors, an effective English learning solution can be implemented afterwards. A teacher as facilitator may assist the students in facing the difficulties using various teaching strategies which are suitable with the digital era nowadays.
\end{abstract}

Keywords: performance, English speaking skills, linguistic factor, learning, motivation, digital era.

\section{INTRODUCTION}

$\mathrm{T}$ The foreign language skills are mandatory for everyone in this era, especially English. This is due to the fact that English has declared as one of the international languages by the United Nation, so its importance becomes more considerable in communication nowadays. English skills, both active and passive competencies should be owned by the people in order to commemorate the rapid development of science and technology. English as a universal language also assists every person to communicate easily without any barriers for various aspects of life. Due to its importance, the Indonesian government use English as a compulsory subject learned in the university.

Due to the rapid movement of digitalisation nowadays, students should be prepared for challenges, especially related to English learning. They have to be capable in understanding English for reading textbooks, journals, online newspaper or articles in English for better knowledge. In addition, speaking and listening skills also may help them in communicating with other colleagues during international open discussion or forum that they can usually access from internet. Hence, learning English plays an important role in the digital era.

University as an educational institution is required to create credible human resources who are ready in competing at job markets after they graduate. One of the competencies they have to be mastered is English speaking skill, but the curriculum of English at university focuses only on passive skills (writing, reading and understanding grammar structures), rather than the active ones (listening and speaking). Meanwhile, speaking is considered as the most important of learning English as a second or foreign language and the successful learning is if the students 
may be able to perform a conversation using English well and other people may understand what they mean without any confusion [1]. Furthermore, the foreign language teaching will be successful if the students may develop the ability in performing English effectively and accurately in communication [2], but many students as the English foreign learners may not be able to do that because they have no proper knowledge in speaking as well as less practice during the learning process.

The Faculty of Social Sciences is also required the students to take English class as a mandatory subject before they graduate, but the previous curriculum only focuses only on reading skills and the basic grammatical rules that they actually have been studied from elementary schools to the higher schools rather than giving a chance for them in practicing and improving their speaking skills. It is because they are non-English student and they think that passing the class with good grade might be the most important thing to reach, not the real competencies.

The aim of this research is to analyse various mistakes which often carry out by the students of FIS UNNES as non-English students, so the factors which influence those performances will be investigate deeply. Hence, the research questions were formulated to this research as follows:

A. How is English speaking performance carried out by students at Faculty of Social Sciences?

B. What are several factors which influence those English-speaking performance?

C. What is the effective language learning used by the lecturers in increasing English speaking performances by the students?

\section{METHODOLOGY}

The method used in this study is called qualitativedescriptive research in order to summarize the comprehensive experiences carried out by individuals or groups [3]. Additionally, this is also used to describe the events, so "it is less interpretive than an interpretive description' approach because it does not require the researcher to move as far from or into the data; and does not require a conceptual or highly abstract rendering of the data, compared to other qualitative design" [4]. The participants of this study are 20 students of Faculty of Social Sciences, Universitas Negeri Semarang. Data were collected through video presentation by the students in performing English speaking for approximately 10-15 minutes explaining particular topics, such as education and learning. The students were asked to create video and uploaded to YouTube to support digital learning. Video observation was carried out by searching the linguistic mistakes by the students. Then, semi-structured interviews were followed to gain information deeply, especially in describing the reasons they study English and the value of English for them, and snowball sampling was used in this research because I chose 10 random people for interviews [5]. Data analysis includes data reduction, data displays and conclusion or drawing verification [6].

\section{RESULTS AND DISCUSSION}

\subsection{Linguistic Mistakes}

According to the observation from 20 videos, most students perform well when presenting the particular topic in English, however, they make several linguistic mistakes such as pronunciation, accent, grammatical structures and vocabulary. The students carry out many mistakes in how they pronounce the English word perfectly, for example the word: through, complete, research, valuable, result, even though, practice, conduct, discussion, higher, policy, study, sciences, belief, honour, study, attachment, entitled, heritage, method, focus etc. They tend to use their mother-tongue accent and pronunciation, that is Bahasa Indonesia or Javanese. English for Foreign Learner's (EFL) speaking skills are affected by some of the linguistic components, namely phonetic and phonology, but the students have no proper linguistic knowledge. It is understandable because they are non-English student, and pronunciation of English words is not as same as the written one, so they find difficulties and cause confusion in pronounce them well [7]. Here, the expected pronunciation is 'intelligible pronunciation ', not the perfect one like the native speaker. It means that the students should produce correct sounds, so other people will adequately understand their meaning [8]. Furthermore, their awareness of correct pronunciation and intonation may be increased if the teacher also involves in the class learning, for example linking pronunciation with listening comprehension and inviting the students to practice the pronunciation together. In other words, the teacher's role is as a coach who give meaningful feedback for the students to improve their pronunciation [9].

Secondly, the students also perform mistakes in using correct vocabulary. From the observation, the student mentioned wrong vocabulary for indicating some words, some examples are provided below. The italic words show the vocabulary mistakes made by the students when speaking English and the correction ones are written in the bracket.

$$
\begin{aligned}
& \text { She plays good (well) } \\
& \text { He has a new work (job) }
\end{aligned}
$$

She loaned a book from library (borrowed)

I will look the movie tonight (watch) 
The examples above indicate that the students have lack of English vocabulary. Furthermore, the mixing of Bahasa Indonesia and English also occurred during the presentation because the students cannot find the exact word, so they prefer using terms in Bahasa Indonesia English vocabulary may be improved by reading many English texts, and it cannot be developed instantly. Reading and listening may also assist them in both recognizing the new words and increasing their ability to use these words in the correct contexts. It is very beneficial for the students as EFL in building their vocabulary, namely: to help them in expressing precisely, to help understanding different accent from other countries, to comprehend the textbooks and articles, discussion, debates which conducted in English and to avoid repetition of using similar words during their speech [10].

Finally, the researcher also found out that the students surely make common mistakes that EFL always do during their speaking performances, namely grammatical errors. The examples are provided below. The italic words show the grammatical mistakes carried out by the students. ... but I has so many questions about culture and
identity...

... They does not believe the myth in ....

The study also uses ...... Data is collected through....

How are you? Hope you doing well...

Character education is carry out...

Do everything good? I'll present...

Understanding grammar structures should be studied gradually, from the basic to the more advance level. It is understandable for the EFL, especially in speaking performances. They find difficulties in building sentences when they are trying to express their ideas even though they sometimes have learned the structures since the higher schools. The teacher should focus on more communicative use of grammar rules rather than the passive skills, for instance encouraging the students to make short and simple sentences each meeting and engaging the students during the class communication activities [11].

\subsection{Non-linguistics Factors Affecting English Speaking Skills}

Based on the interviews conducted to 10 students, they explain the reasons why they cannot speak English well during the class. One of the students [R1] said that he is not confident in speaking English due to the fact that his friends always make fun of him when he is speaking English using his Javanese accent or if he pronounces wrong. In addition, one of the students feels that performing English speaking naturally is highly difficult for her, so she has to prepare everything before she starts talking [R2 and R3]. They have to make notes, practices in front of mirror again and again. $\mathrm{R} 2$ feels nauseous and anxious before she start presenting English in front of her friends. R3 also said that she prefers silent when their friends or teacher start to open conversation because she does not prepare in speaking naturally and confuse in answering the talks properly. Their interviews were transcribed as quotations as follows:

"I am not confident in speaking English in front of my friends because they always laugh at me if I make mistakes. Additionally, I also don't think that I am capable to speak fluently" [R1].

"I could say that learning English is super difficult for me, especially speaking. I am fully pressured when I have to present or to speak in English. I am so frustrated. I feel sick as well.” [R2]

"I have to prepare everything before I speak (in English), I cannot spontaneously speak, so I prefer be quiet." [R3]

Meanwhile, some students also show a negative attitude to English, especially speaking skills. They said that studying English is only important for them in obtaining good grades at class [R4]. Furthermore, they have no interest and do not understand the use of practicing English speaking skill in the future, so they make no effort to learn English. The quotation from the transcribed is presented as follows:

"For me, learning English is not so important. I only want good grade for the subject. That's all!" [R4]

Some of the students said have good proficiency in English speaking skills, such as writing and reading rather than the active skills. They have studied English from elementary schools to the higher schools, however, it only focuses generally on reading, grammar and structures and listening as well. Most of them are rarely taught how to speak English well. Thus, their Englishspeaking skill does not increase gradually. One of the respondents also mentioned that he wants to start learning English speaking due to its importance, but he needs feedback from the master. He shows his interest in increasing his skills, but he does not have partners to practice his English. Many of his friends are shame in speaking English during daily conversation because they think it is weird. 
"I prefer reading what I write rather than speaking naturally in English. I am afraid to make mistake, whether my grammar is correct or not. My pronunciation is good or not. I am always overthinking." [R5]

"I want to perform English well, but I don't know how to start. I am good in reading and listening, but I am not good in speaking. I need more practices and guidance from the master." [R6]

From the findings above, there are various factors demotivating the students in learning English speaking skills. First, the lack of self-confidence and anxiety are one of the significant factors that affect students in learning speaking skills. It is related to the affective factors that may cause the students stop their language learning and performance abilities, so the high level of anxiety and lack of self-confidence lead the students in the lower speaking performances at class [12]. Furthermore, the fear of speaking English is pertinent to some personality like anxiety because adults tend to be more careful in making mistakes in front of people [13] due to the fact that they are two categories of English learners at class, namely the strong and the weak ones. Hence, the weak believes that their speaking ability is very low, so they tend to be quiet during the class activities [14]. Secondly, the negative attitude towards English will be the factor that may decreases the students 'speaking skills. Some students make no effort to learn and show no effort to learn because they lack motivation in speaking, so they said: 'what's use studying English? '. Then, motivation can influence the language learning skills. If the learners have positive attitudes towards the language, they may be more sensitive to pronunciation and accent of the English, so their speaking performances will be rapidly increase [15].

\subsection{Effective Language Learning}

Thus, the teacher as the master or English at class should assist the students in developing their speaking abilities. The use of appropriate activities at class is expected to be a solution in decreasing their anxiety and in increasing self-confidence, for example having a discussion that encourage the students in choosing the topic for the class will urge them to feel more comfortable and then increase their confidence in speaking English [16]. Similarly, the teachers, peers, materials, etc. also cause demotivation of the students, for example the feedback and the reactions from the teachers and their peers when they are making mistakes may both motivate and demotivate them. The teachers as facilitator should rectify the students and keep them motivated if they make mistakes during the class, so they never feel ashamed, do not hesitate to make mistakes and they will involve again in the class discussion [17]. Additionally, students are also recommended to change their preceding mind-set that English is difficult to learn, to stop worrying much about what other persons see about their speaking performance and to stop overthinking about making mistakes that may lead in underestimating their own capabilities [18].

Furthermore, digital era leads students to conduct self-study using modern learning such as the positive use of internet. They may access many sources or references in assisting them in learning English, especially in speaking and listening. For instance, YouTube may provide many videos on how English is pronounced perfectly in different accents across the world. Hence, the teacher may ask the students to find appropriate resources as a class-activity in order to create more interesting materials outside class.

\section{CONCLUSION}

The students of Faculty of Social Sciences Semarang have difficulty in performing English well during English class by carrying out several linguistic mistakes such as pronunciation, intonation, vocabulary and grammatical structures because they have lack of knowledge in understanding those as non-English students. Additionally, non-linguistic factors also influence their performance such as motivation, selfconfidence, anxiety and negative attitudes towards English as foreign language in Indonesia. Hence, the teachers as facilitator should understand each student and motivate them in advance before the class every day and create more exercises and practices in speaking English at class rather than the passive English competencies that they have been studied previously at the higher school. Furthermore, building more fun, friendly and cooperative class environment is expected to help the students increase their enthusiasm and eagerness in speaking English comfortably at class as well as make use of digital learning such as internet in assisting the students to learn something new. For further research, I hope data collection may include the participants in more natural situation, for example discussion because this research conducted during the Covid-19 pandemic situation.

\section{AUTHORS' CONTRIBUTIONS}

The first and second authors contributed to the design and implementation of the research, to the analysis of the results and to the writing of the manuscript. 


\section{ACKNOWLEDGMENTS}

This paper was presented at the 6th International Conference on Education and Social Sciences in April 2021. The researcher would like to say their gratitude to Faculty of Social Sciences in funding this research. Additionally, we also thank all respondents who participate this research, so this paper may be published.

\section{REFERENCES}

[1] Nunan, D. (1995). Language Teaching Methodology: A Textbook for Teachers. NY: Phoenix Ltd., p. 593.

[2] Davies, P., \& Pearse, E. (2000). Success in English Teaching. Oxford University Press.

[3] Lambert, V.A. \& Lambert, C.E. (2012). Qualitative Descriptive Research: An Acceptable Design. Pacific Rim International Journal of Nursing Research, 16(4), 255-256

[4] Sandelowski M. (2000). Whatever happened to qualitative description? Research in Nursing \& Health, 23(4):334-340.

[5] Dörnyei Z. 92007). Research methods in applied linguistics. Oxford: Oxford University Press.

[6] Arikunto, S. (2006). Prosedur Penelitian: Suatu Pendekatan Praktek. Jakarta: Rineka Cipta.

[7] Mahripah, S. (2014). Exploring Factors Affecting EFL Learners' Speaking Performance: from Theories into Practices. Proceedings of the 3rd UAD TEFL International Conference 2014 "Materials Development in Asia and Beyond: Directions, Issues, and Challenges." English Education Department, Universitas Ahmad Dahlan, Yogyakarta, Indonesia.

[8] Morley, J. (1991). The pronunciation component in teaching English to speakers of other languages, TESOL Quarterly, 25(1), 51-74.

[9] Gilakjani, A.P. (2012]. A Study of Factors Affecting EFL Learners' English Pronunciation Learning and the Strategies for Instruction. International Journal of Humanities and Social Science, 2 (3), 119-128.

[10] Manyak, P. C., \& Bauer, E. B. (2009). English Vocabulary Instruction for English Learners. The Reading Teacher, 63(2), 174-176.

[11] Al Hosni, S. (2014). Speaking Difficulties Encountered by Young EFL Learners. International Journal on Studies in English Language and Literature, 2 (6), 22-30.
[12] Tanveer, M. (2007). Investigation of the Factors That Cause Language Anxiety for ESL/EFL Learners in Learning Speaking Skills and the Influence It Casts on Communication in the Target Language. Dissertation, University of Glasgow.

[13] Leong, L. \& Ahmadi, S.M. (2017). An Analysis of Factors Influencing Learners' English-Speaking Skill. International Journal of Research in English Education, 2 (1), 34-41.

[14] Woodrow, L. (2006). Anxiety and Speaking English as a Second Language. RELC Journal, 37(3), 308-328.

[15] Merisuo-Storm, T. (2007). Pupil's Attitudes towards Foreign-Language Learning and the Development of Literacy Skills in Bilingual Education. Teaching and Teacher Education, 23, 226-235.

[16] Boonkit, K. (2010). Enhancing the Development of Speaking Skills for NonNative Speakers of English. Procedia Social and Behavioral Sciences, 2, 1305-1309.

[17] Soureshjani, K.H. \& Riahipour, P. (2012). Demotivating Factors on English Speaking Skill: A Study of EFL Language Learners and Teachers' Attitudes. World Applied Sciences Journal, 17 (3), 327-339.

[18] Haidara, Y. (2016). Psychological Factor Affecting English Speaking Performance for the English Learners in Indonesia. Universal Journal of Educational Research, 4 (7): 15011505. 